\title{
Wildlife and damage to agriculture: an ethnobiological approach with rural producers in southeastern Brazil
}

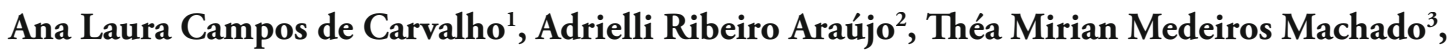 \\ Rômulo Ribon ${ }^{1,2}$ \& Leonardo Esteves Lopes ${ }^{4,5}$
}

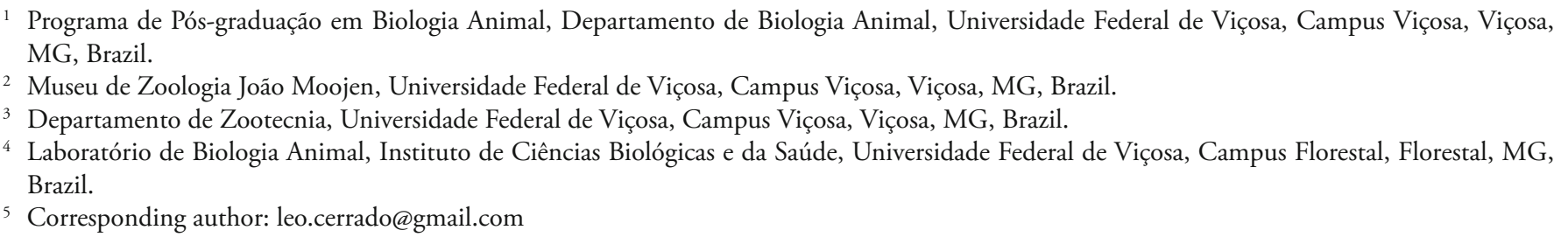

Received on 03 October 2018. Accepted on 06 March 2019.

\begin{abstract}
Some wild animal species quickly adapt to anthropogenic environments, producing unusually large populations, causing human-wildlife conflicts. The objective of this study is to understand the way the farmers perceive the fauna and the information they possess regarding the damages those animals inflict on their crops in southeastern Brazil. We collected data by presenting 200 questionnaires and conducting 22 semi-structured interviews with the rural producers in a region characterized by an agrarian matrix intermixed with small forest patches. Nearly every rural producer (99\%) who answered the questionnaire $(n=$ 107) had suffered wild animal-triggered economic losses, especially by the White-eyed Parakeet Psittacara leucophthalmus (51\%), which attacked maize and fruit crops. A substantial portion of these farmers (38\%) has employed some control method, including acoustic techniques (42.5\%), like fireworks, and visual techniques (41\%), like scarecrows. The farmers concurred that effective control methods are necessary for the White-eyed Parakeet, as current techniques proved inadequate. The understanding that the rural producers possess about the problem will facilitate designing new control strategies to manage this pest species. However, to ensure its success, a suitable management plan must be formulated to guarantee that the local rural occupations are maintained, incorporating human dimensions into wildlife management.
\end{abstract}

KEY-WORDS: crops damage, ethnozoology, human-wildlife conflict, problem species, Psittacidae.

\section{INTRODUCTION}

Vast sections of almost all the world ecosystems have been converted into landscapes predominantly for human exploitation, particularly farming (Greenberg et al. 1997, Daily et al. 2001), thus negatively affecting most wild species and their populations (McLaughlin \& Mineau 1995, Verhulst et al. 2004). However, the extension of agricultural locations may also result in the population explosion of some species, partly due to the associated rise in the food, as well as resting and reproduction sites becoming more available (Singleton et al. 1999, Koopman $\&$ Pitt 2007).

Any animal species in an agricultural ecosystem which shows disproportionate and unrestrained population explosion frequently poses a problem for man (Fall \& Jackson 2002). Such human-wildlife conflicts mostly originate from the economic losses these species inflict on the rural owners (Tracey et al. 2007), inducing a change in their perception of the wildlife (Messmer
2009). Thus, wild fauna, normally accepted as being economically, recreationally, and aesthetically useful, are hence considered undesirable and problematic (USDA 1997, Conover 2001, Ormerod 2002).

Any living organism having a population density that directly or indirectly impinges on society, injuring its health and constructions, or influencing plantations of food crops and raw materials, thus necessitating control methods, is defined as a pest species (Sinclair et al. 2006). Control management techniques to tackle these pest species attempt to diminish the damage they cause, either by blocking or decreasing the accessibility of the species to food sources or reducing its population growth (Moreira \& Piovezan 2005, Sinclair et al. 2006).

A global war is on between wildlife and agriculture with serious economic backlashes (de Grazio 1978). Each problem is unique to the social and cultural contexts of the part of the world where it happens, in terms of the species involved and the types of region they inhabit (Beasley $\&$ Rhodes-Jr. 2008, Rao 2010). Therefore, workable, and 
long-term control methods are required to minimize the damage to agriculture caused by wildlife (Messmer 2009). To successfully manage the control of the human-wildlife conflict a correct understanding of the affected and unaffected actors in society is required (Conover 2001), as well as the knowledge of the positive and negative sides of the various management alternatives, keeping the focus of wildlife conservation intact (Brook 2009). In this context, an ethnobiological approach is highly desirable, because it has the "potential to integrate local and global knowledge, connect cultures and academic approaches, and to relate biological and social aspects of the human experience to the environment" (Albuquerque \& Alves 2016).

Brazil ranks high among the leading food producers and exporters worldwide (OECD-FAO 2015); however, despite facing serious conflict between wildlife and agriculture, very little study has been done (Moreira \& Piovezan 2005), with the result that management strategies for problem species of birds are few or absent. Therefore, farmers frequently implement rather inadequate selfdeveloped practices, a few of which do more damage to the environment. Given that human-wildlife conflict is a growing issue in Brazil (Marchini \& Crawshaw-Jr. 2015), the objective of this study is to understand the way the farmers perceive the fauna and the information they possess regarding the damages those animals inflict on their crops in southeastern Brazil.

\section{METHODS}

\section{Study area}

We conducted this study in 12 municipalities in the southeast of the state of Minas Gerais, Brazil, in a region known as Campo das Vertentes (between $21^{\circ} 00^{\prime} \mathrm{S}-21^{\circ} 40^{\prime} \mathrm{S}$; $\left.43^{\circ} 20^{\prime} \mathrm{W}-45^{\circ} 20^{\prime} \mathrm{W}\right)$ (Fig. 1). The original vegetation of the region, which is in the transition between the Cerrado and the Atlantic Forest, was a mosaic composed by montane semideciduous forests, open savannas, and pure grasslands (Azevedo 1962, Gavilanes et al. 1995, Oliveira-Filho \& Fluminhan-Filho 1999, IBGE 2012). The climate of the region, which is mostly between 1000 and $1200 \mathrm{~m}$ altitude, is humid temperate, with hot wet summers and cold dry winters (Cwb-Köppen's climate classification system) (Alvares et al. 2013), with average annual temperatures varying locally between $17.4^{\circ} \mathrm{C}$ and $20.5^{\circ} \mathrm{C}$, and annual average precipitation varying between 1200 and $1600 \mathrm{~mm}$ (Naime et al. 2006).

Currently, the landscape of the Campo das Vertentes is highly modified and fragmented, with a mosaic of

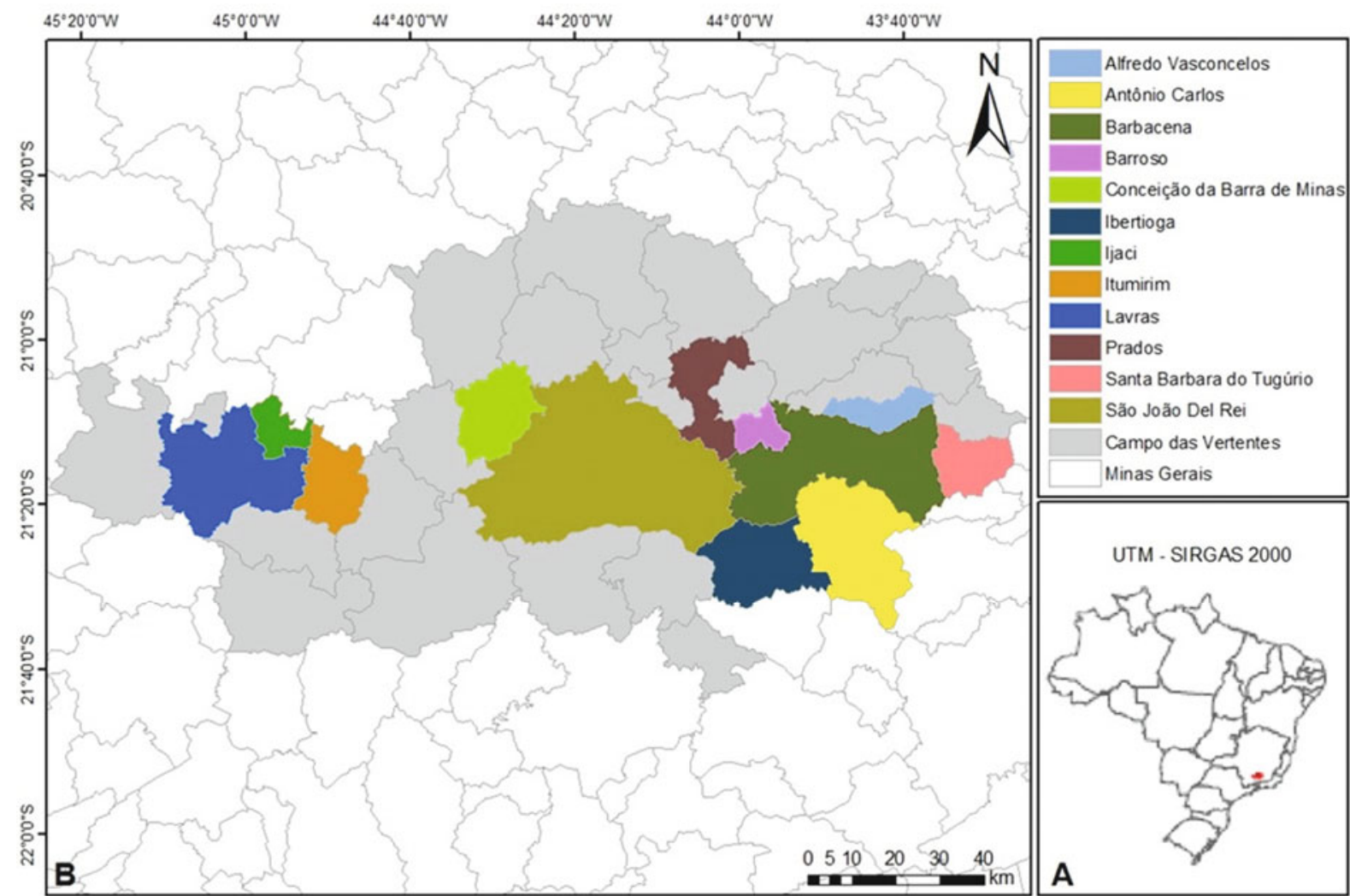

Figure 1. Location of the study area in the Campo das Vertentes region (A), the municipalities involved in the research are highlighted in color $(\mathbf{B})$. 
small forest fragments, agricultural areas, Eucalyptus plantations, and artificial pastures for livestock raising (Lopes et al. 2010, A.L.C.C. pers. obs.). According to an unpublished report of EMATER-MG ("Safra Agricola 2014"), local agriculture is characterized by plantations of fruit, maize, sorghum, soybean, beans, coffee, and vegetables, with most farmers being small and mediumsized rural owners.

\section{Data collection}

Between July and September 2014, we collected data via questionnaires and semi-structured interviews. We distributed a total of 200 questionnaires, among which 120 were administered in collaboration with EMATERMG, which sent out 10 questionnaires to each of their 12 local offices in the cities of Alfredo Vasconcelos, Antônio Carlos, Barbacena, Barroso, Conceição da Barra de Minas, Ibertioga, Ijaci, Itumirim, Lavras, Prados, Santa Bárbara do Tugúrio, and Sáo João del-Rei (Fig. 1). We administered the remaining 80 questionnaires during meetings with farmers from the Rural Union of Barbacena ("Sindicato Rural de Barbacena") and the National Program of Access to Technical Education and Employment (PRONATEC), both held in Barbacena. The semi-structured questionnaire included 13 objective questions (answerable briefly or with yes/no) dealing with the relationship between wildlife and its agricultural impact (Ditt et al. 2009).

Using the semi-structured questionnaires, we conducted face-to-face interviews with 22 fruit growers, maize and sorghum from Barbacena. The main issues in the interviews addressed the level of damage, control techniques, species behavior and population variations that the farmers experienced with their respective pest species on the agricultural crops. To verify the pest species cited by the farmers, we presented illustrations and a list of likely problem species that could occur in the region.

Besides questionnaires and interviews, we also accessed the rural producers' perceptions during a meeting conducted in March 2014 at the Rural Union of Barbacena. They discussed the conflict between the fauna and agriculture and the pest management control methods prevalent in Brazil and the alternative methods available in the rest of the world. This meeting facilitated profitable dialogue among the rural producers and an exchange of experiences.

\section{RESULTS}

\section{Questionnaires}

There was a $53.5 \%$ (107 of 200) response rate to the questionnaire from the 12 local EMATER-MG offices:
Alfredo Vasconcelos $(n=9)$, Antônio Carlos $(n=10)$, Barbacena $(n=5)$, Barroso $(n=5)$, Conceição da Barra de Minas $(n=7)$, Ibertioga $(n=10)$, Ijaci $(n=10)$, Itumirim $(n=10)$, Lavras $(n=10)$, Prados $(n=4)$, Santa Bárbara do Tugúrio $(n=1)$, and São João del-Rei $(n=5)$. We obtained 21 questionnaires from the meetings with the farmers at the Rural Union of Barbacena and the meeting with the PRONATEC farmers.

The farmers mentioned the most frequently cultivated agricultural products in the region and their respective areas in hectares (ha) as maize $(52 \%$ of the producers; grown on 0.5 to 55 ha), fruits $(22.4 \%$; on 5 to $130 \mathrm{ha})$; vegetables $(12.8 \%$; on 1 to $3 \mathrm{ha})$, beans $(9.6 \%$; on 0.5 to $20 \mathrm{ha})$, sorghum ( $2 \%$; on 0.5 to $5 \mathrm{ha}$ ), rice $(0.6 \%$; on $0.5 \mathrm{ha})$, and sugarcane $(0.6 \%$; on $3 \mathrm{ha})$. The cultivated areas within a farm were thus usually small, below 10 ha. With only one exception, all farmers had experienced economic losses induced by wild animals.

Among the 16 animals identified as the cause of economic losses (Table 1), the White-eyed Parakeet Psittacara leucophthalmus was the most problematic as mentioned in the questionnaires by $51 \%$ of the producers, principally on maize (36.4\%) and fruits (13.5\%) (Fig. 2 \& 3). All producers mentioned a significant increase in the local population of this species over the recent years. Capybara (Hydrochoerus hydrochaeris) was the second most

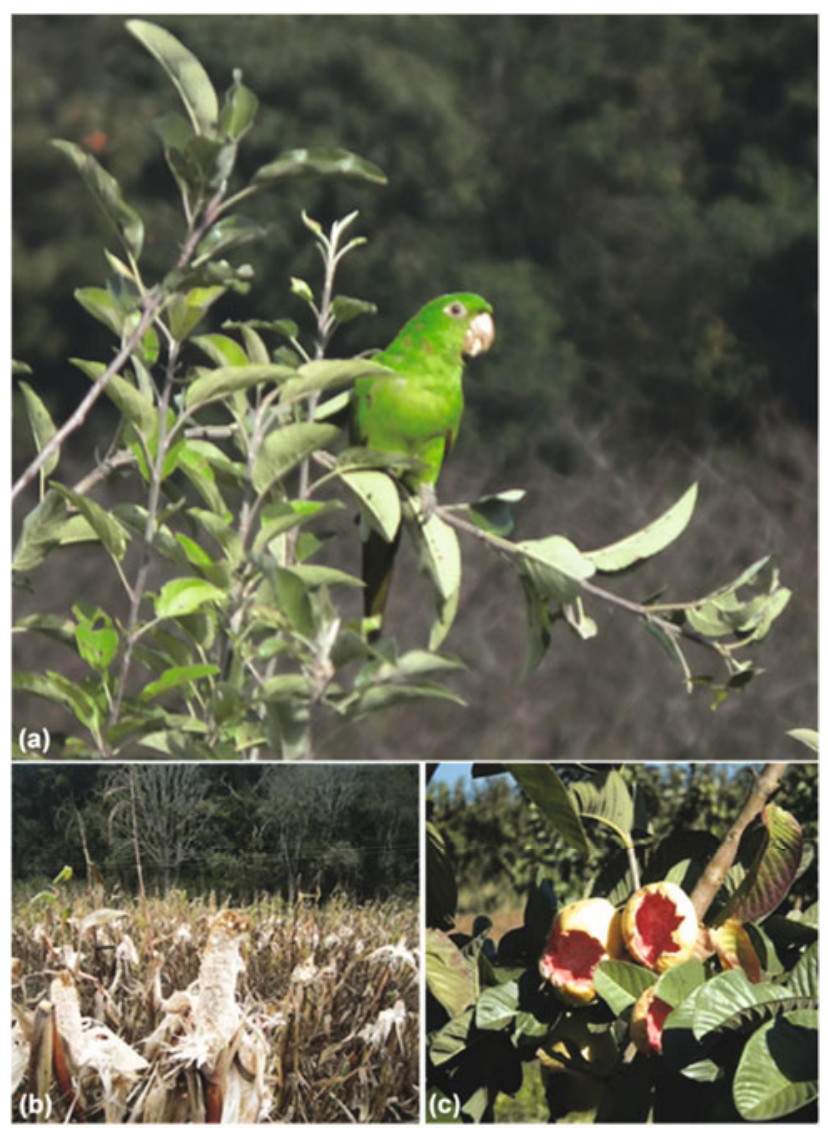

Figure 2. Damage caused by White-eyed Parakeets Psittacara leucophthalmus (a), in maize (b) and guava (c) crops in southeastern Brazil. Photo author: Ana Laura C. Carvalho. 
Table 1. Damage-causing vertebrate pests on agricultural crops in the southeastern Minas Gerais, Brazil.

\begin{tabular}{lll}
\hline Taxon & English name & Scientific name \\
\hline BIRDS & & \\
Galliformes & Dusky-legged Guan & Penelope obscura \\
Gruiformes & Slaty-breasted Wood-Rail & Aramides saracura \\
Columbiformes & Pigeon & Patagioenas spp. \\
Piciformes & Toco Toucan & Ramphastos toco \\
Cariamiformes & Red-legged Seriema & Cariama cristata \\
Psittaciformes & White-eyed Parakeet & Psittacara leucophthalmus \\
Passeriformes & Curl-crested Jay & Cyanocorax cristatellus \\
Passeriformes & Chopi Blackbird & Gnorimopsar chopi \\
Passeriformes & Tanager & Thraupis spp. \\
MAMMALS & & \\
Rodentia & Capybara & Hydrochoerus hydrochaeris \\
Artiodactyla & Wild Boar & Sus scrofa \\
Carnivora & South American Coati & Nasua nasua \\
Cingulata & Armadillo & Dasypodidae spp. \\
Didelphimorphia & Opossum & Didelphis sp. \\
Primates & Howley Monkey & Allouatta sp. \\
\hline
\end{tabular}

${ }^{a}$ The Wild Boar is an exotic species in Brazil, and in the region, it probably refers to a cross between the Domesticated Pig (Sus scrofa domesticus) and the Wild Boar (Sus scrofa scrofa).

cited species ( $11 \%$ of the producers), causing problems mostly on maize crops (9\%), while the Dusky-legged Guan (Penelope obscura) was the third most mentioned species (10\% of the producers), chiefly on bean ( $4 \%)$ and vegetables (3.6\%) (Fig. 3).

A significant degree of financial loss was attributed to wild animals by $72 \%$ of the rural producers. The problematic species included those that inflicted economic losses (81\%), which could not be controlled by

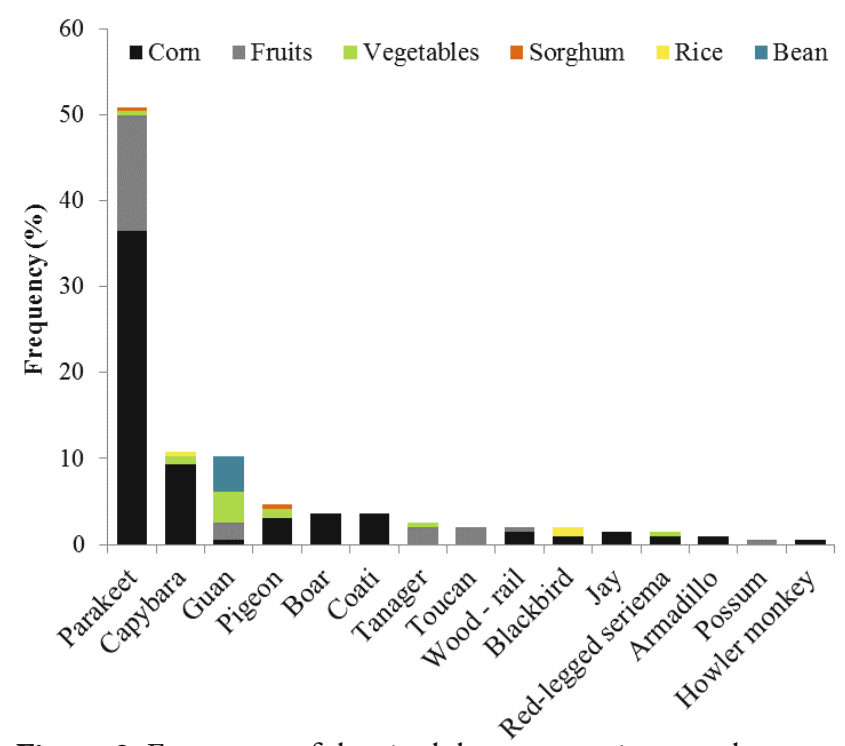

Figure 3. Frequency of the cited damage-causing vertebrates on agricultural crops in southeastern Brazil. the currently used management techniques (13\%), and those with huge populations that attacked the food crops $(6 \%)$. All the producers unanimously bemoaned the lack of government support in preventing the financial losses these wild animals caused.

Most of the rural producers (57\%) stated in the questionnaire that September to December was the period when the animals most attacked plantations. Crop damage, however, continued the whole year through.

From the questionnaires, it was evident that $38 \%$ of the rural producers who experienced financial losses caused by the wild fauna used some control measures. The commonest techniques used by $42.5 \%$ of the producers were of the acoustic type (e.g., fireworks, gas cannon, and other devices producing a variety of sounds), but with marginal success, whereas $41 \%$ of the producers employed the visual types (e.g., scarecrows, reflectors, and lookouts on foot and on motorcycle) (Fig. 4).

The control methods employed by the rural producers were generally regarded as ineffective, with only $12 \%$ registering any decrease in the degree of damage and $88 \%$ denying any positive outcomes. Reportedly, the White-eyed Parakeet quickly got used to the acoustic (fireworks) and visual control methods (scarecrows, reflectors) (Fig. 5A-D). Measures such as human or motorcycle riding lookout should be continuously applied in these areas to gain some success (Fig. 5E-G). 
However, they reported that such methods only changed the location of the problem, as the animals moved on to neighboring plantations for food. Total isolation of the White-eyed Parakeet-affected plantations, by covering them with protective (drape over) netting, was regarded as economically unfeasible (Fig. $5 \mathrm{H} \& \mathrm{I}$ ).

While most rural producers (69\%) strenuously

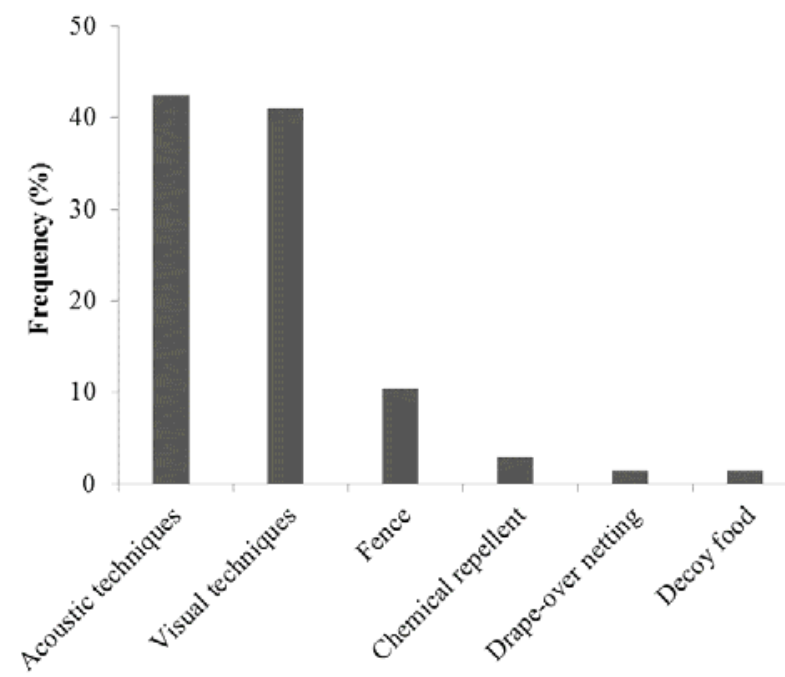

Figure 4. Frequency of implementing various types of control measures by the rural producers in southeastern Brazil. denied any hunting on their property, 19\% acknowledged it was prevalent and $12 \%$ did not comment about this management technique. Among those who admitted to hunt, birds (9.5\%) and mammals (90.5\%) were sought as food (67\%), sport and leisure (19\%), and as pest extermination (14\%). A little below half the rural producers (44\%) acknowledged they would hunt wild animals legally and with control, while $56 \%$ stated they would not indulge in hunting. The reasons proffered for avoiding hunting included not being habituated to hunt, disliking the concept, lacking the courage to kill an animal, lacking time and resources, or even because several animals had become extinct.

All the rural producers unanimously agreed among the many suggestions offered that pest species required management, such as controlled hunting (48.5\%) and interventions to reduce their populations (26\%) (Fig. 6).

\section{Interviews}

All the farmers interviewed indicated that the Whiteeyed Parakeet was the chief pest species in the region. The main damages caused by the species and its impacts are mentioned below:

As it is no longer economically feasible to cultivate
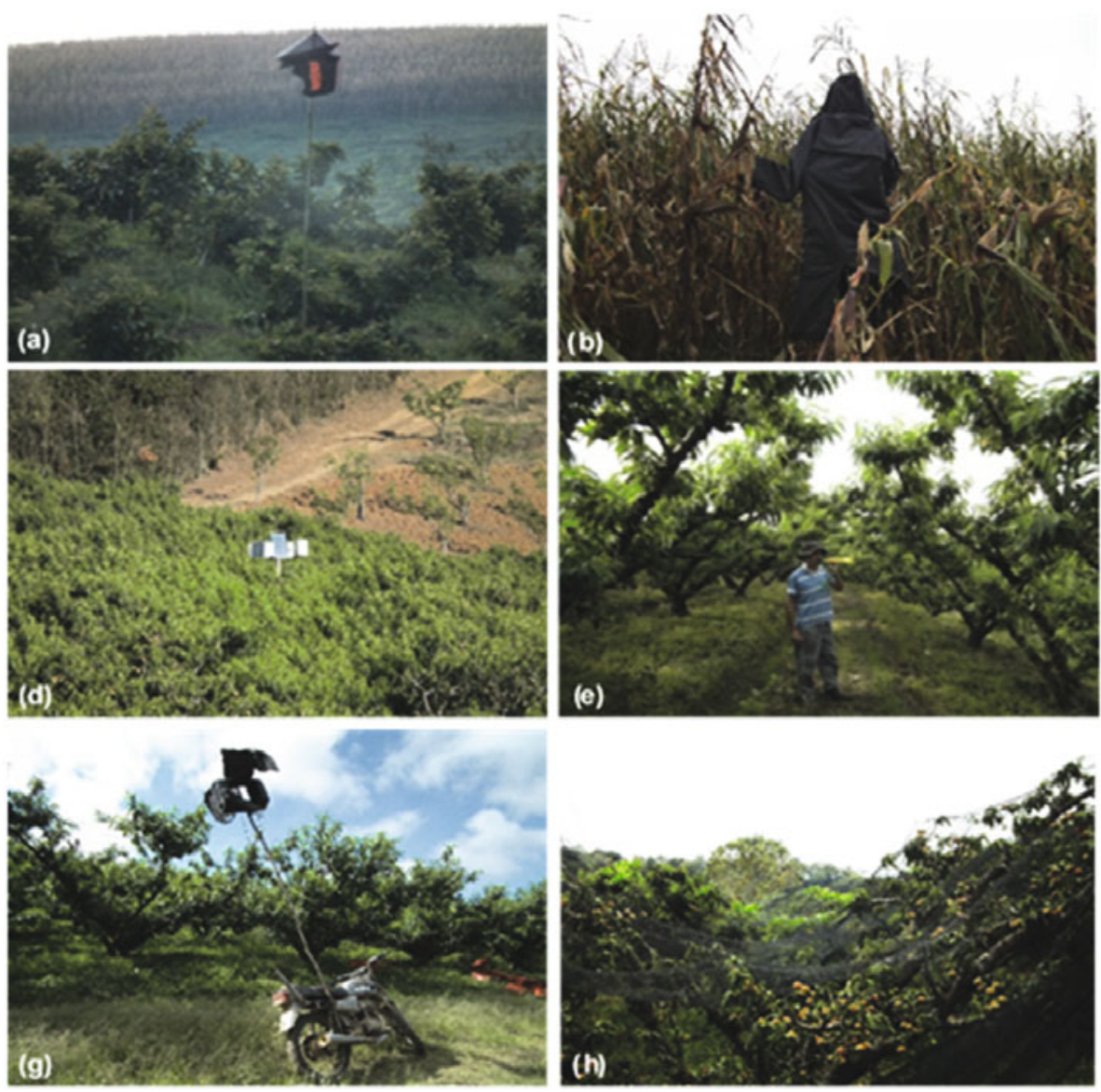
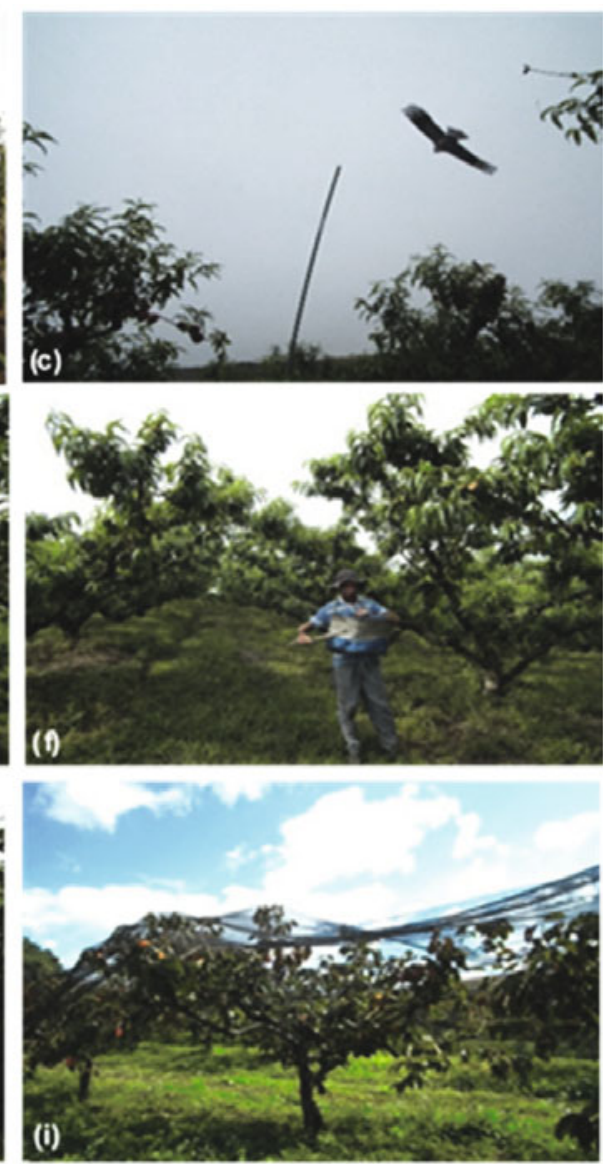

Figure 5. Control methods utilized by the rural producers in southeastern Brazil. Scarecrows (A-C); reflectors (D); lookout on foot $(\mathbf{E} \& \mathbf{F})$; lookout on motorcycle $(\mathbf{G})$, protective netting $(\mathbf{H} \& \mathbf{I})$. Photo author: Ana Laura C. Carvalho. 


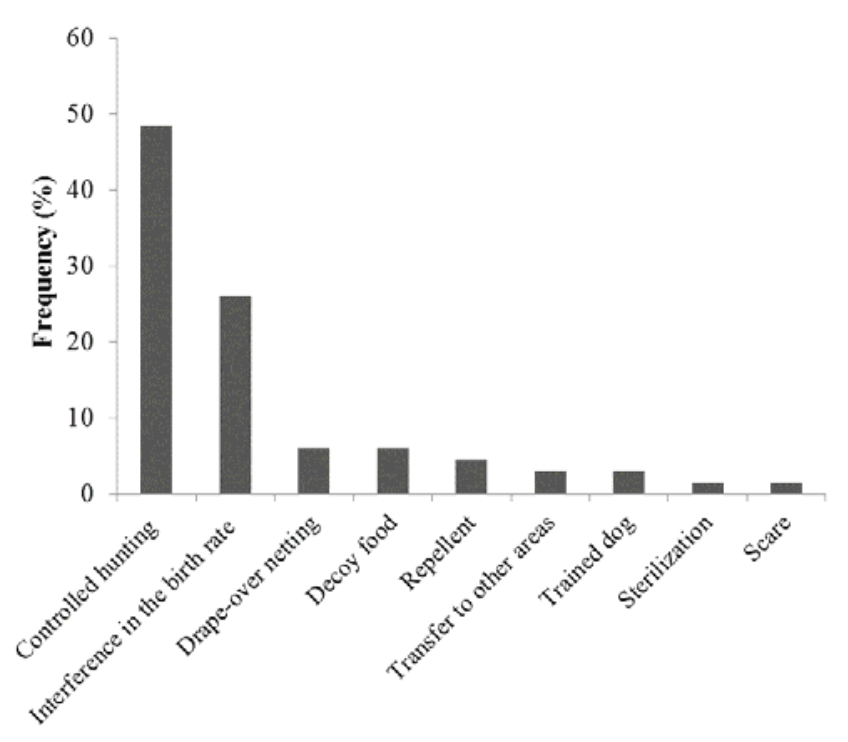

Figure 6. Popular methods advocated by farmers as potential control methods for wildlife posing problems species posing problems to crops in southeastern Brazil.

fruits and maize in the region because of the large extent of financial loss caused by White-eyed Parakeet attacks, many rural producers have ceased to do so;

Electrical wiring and house tiles are frequently damaged;

The White-eyed Parakeet population has exploded over the last few years when compared to its numbers 15 years ago, at which time the economic damage inflicted was minimal;

The White-eyed Parakeet population thrives through the whole year in the region because food is readily available (crop cycle of fruits, maize and sorghum);

White-eyed Parakeet prefer grains and seeds (maize and the weed Jaegeria hirta, Asteraceae), over fruits, and feed mainly on apple, peach, and guava;

During the fruit harvest, the White-eyed Parakeet stay in the orchards throughout the entire day, aggregating in communal roosts to overnight close to the food supply;

Although the White-eyed Parakeet come to the orchards in small flocks of up to 50 individuals, they gradually grow into large groups up to 300 individuals;

Once they eat the first fruit, White-eyed Parakeets always return to the place. Frightening them most often is not the solution, as they quickly return after landing in other parts of the orchard and damaging the fruits there;

Nests are built inside cavities excavated in dirt banks and ravines of inside house roofs, with hatching occurring from December to March, producing up to four youngs per clutch;

When a new method is employed to scare the White-eyed Parakeet from the orchards, they refrain do not immediately return to the area, perching in the trees nearby until they realize that the scaring technique poses no real threat;
The short-term control methods (visual and acoustic) tested were found to have poor effect, as the White-eyed Parakeet are intelligent and quickly get accustomed to them;

While protective netting works more efficiently than the short-term measures, the cost-benefit balance must be considered;

Cultivation of maize varieties with harder kernels could minimize the White-eyed Parakeet attacks;

When maize was planted near the Guava cultivations, White-eyed Parakeet induced damage to the Guavas decreased;

Agronomic crop management techniques (pruning and dormancy control) may reduce economic losses, because it may help circumvent the period of the most intense White-eyed Parakeet attacks;

The White-eyed Parakeet population requires more efficient control measures, as the ones presently in use have been proven to be ineffective in solving the issue.

\section{DISCUSSION}

Economic losses in agricultural crops due to wild animals is a global issue, involving implications for species preservation, agricultural sustainability, and socioeconomic problems (Nyhus et al. 2000). Several species of Psittaciformes, such as the White-eyed Parakeet, are the main consumers of grains and fruits in most agricultural pockets across the world (Long 1985, Bucher 1992, Galetti 1993, Santos-Neto \& Gomes 2007, Tracey et al. 2007, Ahmad et al. 2012). Minas Gerais state, for example, experienced significant economic losses from the White-eyed Parakeet in sorghum (Jacinto et al. 2007), maize, and guava crops (Mateus 2013).

Besides destroying crops, the White-eyed Parakeet have also reportedly damaged electrical wiring and roofs of civilian buildings in the western parts of Minas Gerais (Saiki et al. 2009). In Australia, the Rose-breasted Cockatoo Eolophus roseicapilla causes great damages in urban regions, destroying electric wires, wooden frames, and communication antennae (Tracey et al. 2007).

Bird pests have been recorded to inflict greater agricultural damage in the dry seasons, when food resources in nature are scarce and irrigated crops offer abundant food and water supplies (de Grazio 1978). Although in the current study the White-eyed Parakeet attacks were reported in the orchards mostly between the end of the dry season and the commencement of the rainy season, it is not easy to propose any relationship considering this, as this period is also the peak harvest time for the commercial fruits. The White-eyed Parakeet foraging behavior, as reported by the local farmers, bears similarity to that reported for other species of 
Psittaciformes in Australia, which repeatedly return to the feeding sites if the food supply is available, and set up their communal roosts close to the agricultural crops (Tracey et al. 2007).

The control measures implemented by the farmers were ineffective and frequently economically unfeasible. Common methods used to scare birds (visual and acoustic) are usually poorly efficient, as birds quickly accustom themselves to them (Booth 1994, Tracey et al. 2007, Cook et al. 2008). When preventive control methods are applied (e.g., just prior to fruit formation), they may possibly exert a greater effect (Booth 1994).

A few rural producers (1.5\%) employed protective netting as an effective control measure. Although it has been proven to be effective in minimizing bird damage over the short-, medium- and long-terms (Fisher 1992, Canavelli 2010), it continues to be less implemented because it is not easy to handle (Pritts 2001, Bishop et al. 2003, Simon 2008), as well as due to its high cost (Curtis et al. 1994, Somers \& Morris 2002).

Some farmers $(3 \%)$ mentioned utilizing chemical repellents as a control method, although none indicated the nature of these products. Brazil, to the best of our knowledge, has not regulated the use of any secondary chemical (toxic) repellant and no testing has been conducted by any scientific study on primary (non-toxic) chemical repellents as a control method for bird pests. In the US, some studies are available on the use of primary chemical repellents as a type of bird-pest control, but a varying degree of success have been reported with their use (Avery 2002, Avery \& Cummings 2003).

Agronomic practices of pruning management and dormancy control implemented by some farmers during this study have been recommended by other authors as well, as they can reduce bird damage and raise yields (Canavelli 2009 \& 2010, Linz et al. 2011). Cultivating alternative food sources like maize, in proximity to a vulnerable crop, is also an effective method of decreasing short-term bird damage. However, it must also be understood that these alternative crops are costly and may not be able to satisfy all the birds in the population, especially in the medium- long-term, resulting in even greater damage to the target crops (Bishop et al. 2003).

We collected contradicting reports from the rural producers on the perception of hunting; this was because despite a great majority a great majority of them stating that hunting was absent in their communities $(69 \%)$ and/or that they would refrain from practicing it (56\%), many producers $(74.5 \%)$ suggested hunting and birth interference as population control measures. Hunting wildlife is legally prohibited in Brazil (Federal Law No. 5197, from 1967) and considered an environmental crime (Federal Law No. 9605, from 1998). Therefore, it is expected that rural producers are wary of discussing this subject and, in the rural communities visited during this study, only a few confirmed hunting, even if the problem was a recurrent one (Pinto et al. 2012).

However, hunting pest species in Brazil can be allowed under special circumstances without it being considered a crime. Article 37 of the Brazilian Environmental Crimes Law states, "it is not a crime to slaughter an animal when it is carried out: because it is harmful, as long as it is characterized by the competent agency" (Brazil 1998). Thus, the Monk Parakeet Myiopsitta monachus featured among the species authorized for slaughter in Rio Grande do Sul (IBAMA 2004a). The introduction and explosion of the wild populations of the European Wild Boar in several Brazilian municipalities has recently instigated successive normative instructions to hunt down these animals (IBAMA 2004b).

The sustainable exploitation of wild animals in the Sustainable Development Reserves in Brazil was foreseen by the National System of Conservation Units (Decree No. 4340, 22 August 2002). For instance, hunting chelonians, mammals, and birds, which have been the protein supply for traditional communities, regularly occurs in the Amanã Sustainable Development Reserve, central Amazon (Valsecchi \& Amaral 2009). IBAMA (2005) authorized a regulated trial period of commercial management of the Yacare Caiman Caiman yacare in the Pantanal wetlands, in which a section of the production cycle takes place in the wild. Such initiatives imply that Brazil may try new temporary and experimental wildlife management regulations.

According to the local producers, population control of the White-eyed Parakeet in the Campo das Vertentes region needs more effective methods than those presently utilized, as the problem continues unsolved. This is because any pest population which is stable in an undesirable size, and inflicting economic losses on the farmer or his property, must have its population reduced and maintained by management activities (Caughley $\&$ Sinclair 1994).

Controlling a population by using lethal methods is legally restricted, toilsome, and questionable both ethically and socially, and frequently, it is inefficient in minimizing bird damage (Tracey et al. 2007). For instance, the usefulness of the method may be directly influenced by compensatory responses in the reproduction and survival rates of the pest species (Feare 1991). A few authors propose that in cases of small isolated populations and where immigration can be prevented, reducing populations may be possible (Dolbeer 1998, Feare 1991). However, no published study is available that demonstrates that either short- or long-term lethal control of birds can minimize crop damage (Tracey et al. 2007). For those pest birds having high reproductive rates, control measures implemented during the reproductive 
cycle (e.g., destruction of eggs and nests) may prove more successful than any control exerted during maturity (Paton et al. 2005). With respect to the bird breeding inhibitor (Diazacon), a few studies conducted on the Monk Parakeets revealed hopeful outcomes (Avery et al. 2006).

Implementing management measures in agriculture poses a challenge, as no single control technique is available which can produce prompt and economically effective outcomes (Canavelli 2009). Frequently, several simultaneous or sequential control methods need to be utilized to get the most effective results in minimizing the losses inflicted by the wild birds. It is important though to implement the techniques selected on a suitable spatial scale and, particularly, in foreseeing the damages (Dolbeer 1990 \& 1998, Bruggers et al. 1998, USDA 2010). Monitoring and assessment of the results is fundamental to success, as only then can the most effective strategies be identified, as well as the ways they can be modified to suit the program for the next year (Canavelli 2010).

Finally, while man-wildlife conflicts are being addressed, wildlife managers should consider the needs of all the participants directly affected, as well as be conscious of the range of environmental, socio-cultural, and economic factors involved. Therefore, it is necessary to be sensitive to various perspectives and values and strike an accurate balance between the needs of humans and wildlife (USDA 1997).

We conclude that the conflicts revealed by the rural producers in southeastern Brazil with the pest species identified are due to the financial losses they inflict by damaging the crops of fruits and grains. Farmers are helpless and unable to effectively deal with the problem, as the control techniques used by them are either unviable or inadequate. The knowledge and perception of the rural producers in the region are evidently significant in drawing up and designing implementable management and control measures of the pest species. The ethnobiological study conduct here was a first step to understand the problem. However, more detailed studies on the biology of pest species and the intrinsic features of each crop are required to enable drawing up an elaborate management plan on wildlife control based on three principal aspects: man, animal and habitat. This will be the only possible way of ensuring that rural activities, and wildlife, can be sustained.

\section{ACKNOWLEDGEMENTS}

The study was approved by the Human Research Ethics Committee of the Universidade Federal de Viçosa (Number 698.952/2014; Presentation Certificate for Ethical Assessment: 30744014.9.0000.5153) and follows the ethical standards of the Resolution 196/96 of the Brazilian National Health Council. All the individual participants included in the study gave informed consent per the requirements of the Resolution 466/2012 of the Brazilian National Health Council. A.L.C.C. received a scholarship from the Coordenação de Aperfeiçoamento de Pessoal de Nivel Superior. L.E.L. received a research fellowship from Conselho Nacional de Desenvolvimento Cientifico e Tecnológico (305401/2014-9). Thanks is due also to the Sindicato Rural de Barbacena and the Instituto Federal de Educação, Ciência e Tecnologia do Sudeste de Minas Gerais - Campus Barbacena, for the cooperation and logistical support extended in this project, specifically to Fernando Martins Costa who enabled such a partnership, as well as to the transportation division for their support in all the field collections. Sincere appreciation is expressed to the local offices of the Empresa de Assistência Técnica e Extensão Rural de Minas Gerais. The rural producers have willingly made significant facts and data available for this study. José Eugênio Côrtes Figueira and an anonymous reviewer presented valuable comments on an earlier version of this manuscript.

\section{REFERENCES}

Ahmad S., Khan H.A., Javed M. \& Rehman K.U. 2012. An estimation of Rose-ringed Parakeet (Psittacula krameri) depredations on citrus, Guava and Mango in orchard fruit farm. International Journal of Agriculture and Biology 14: 149-152.

Albuquerque U.P. \& Alves A.G.C. 2016. What is Ethnobiology? p. 3-7. In: Albuquerque U.P. \& Alves R.R.N. (eds.). Introduction to ethnobiology. New York: Springer.

Alvares C.A., Stape J.L., Sentelhas P.C., Gonçalves J.L.M. \& Sparovek G. 2013. Köppen's climate classification map for Brazil. Meteorologische Zeitschrift 22: 711-728.

Avery M.L. 2002. Avian repellents, p. 122-128. In: Plimmer J.R. (ed.). Encyclopedia of agrochemicals, v. 1. New Jersey: John Wiley \& Sons.

Avery M.L. \& Cummings J.L. 2003. Chemical repellents for reducing crop damage by Blackbirds, p. 41-48. In: Linz G.M. (ed.). Management of North American Blackbirds. Colorado: National Wildlife Research Center.

Avery M.L., Lindsay J.R., Newman J.R., Pruett-Jones W. \& Tillman E.A. 2006. Reducing Monk Parakeet impacts to electric utility facilities in south Florida, p. 125-136. In: Feare C.J. \& Cowan D.P. (eds.). Advances in vertebrate pest management, v. 4. Fürth: Filander Verlag.

Azevedo L.G. 1962. Tipos de vegetação do sul de Minas e campos da Mantiqueira (Brasil). Anais da Academia Brasileira de Ciências 34: 225-234.

Beasley J.C. \& Rhodes-Jr. O.E. 2008. Relationship between Raccoon abundance and crop damage. Human-Wildlife Conflicts 2: 248259.

Bishop J., McKay H., Parrott D., \& Allan J. 2003. Review of international research literature regarding the effectiveness of auditory bird scaring techniques and potential alternatives. London: Department for Environment, Food and Rural Affairs.

Booth T.W. 1994. Bird dispersal techniques, p. 19-24. In: Hygnstrom S.E., Timm R.M. \& Larson G.E. (eds.). Prevention and control of wildlife damage. Lincoln: University of Nebraska Cooperative Extension/United States Department of Agriculture. 
Brasil. 1998. Lei 9605 de 12 de fevereiro de 1998. https://www2. camara.leg.br/legin/fed/lei/1998/lei-9605-12-fevereiro-1998365397-publicacaooriginal-1-pl.html (Access on 20 April 2019).

Brook R.K. 2009. Historical review of Elk-agriculture conflicts in and around Riding Mountain National Park, Manitoba, Canada. Human-Wildlife Conflicts 3: 72-87.

Bruggers R.L., Rodriguez E. \& Zaccagnini M.E. 1998. Planning for bird pest problem resolution: a case study. International Biodeterioration and Biodegradation 42: 173-184.

Bucher E.H. 1992. Neotropical parrots as agricultural pests, p. 201-219. In: Beissinger S.R. \& Snyder N.F.R. (eds.). New World parrots in crisis: solutions from conservation biology. Washington: Smithsonian Institution Press.

Canavelli S.B. 2009. Recomendaciones de manejo para disminuir los daños por palomas medianas en cultivos agrícolas. Instituto Nacional de Tecnologia Agropecuaria. http://inta.gob.ar/ documentos/recomendaciones-de-manejo-para-disminuir-losdanos-por-palomas-medianas-en-cultivos-agricolas (Access on 10 June 2014).

Canavelli S.B. 2010. Consideraciones de manejo para disminuir los daños por aves en Girasol. INTA - Estación Experimental Agropecuaria Rafaela, Publicación Miscelánea 118: 175-190.

Caughley G. \& Sinclair A.R.E. 1994. Wildlife ecology and management. Williston: Blackwell Science.

Conover M. 2001. Resolving human-wildlife conflicts: the science of wildlife damage management. Boca Raton: CRC Press.

Cook A., Rushton S., Allan J. \& Baxter A. 2008. An evaluation of techniques to control problem bird species on landfill sites. Environmental Management 41: 834-843.

Curtis P.D., Merwin I.A., Pritts M.P. \& Peterson D.V. 1994. Chemical repellents and plastic netting for reducing bird damage to sweet cherries, blueberries, and grapes. HortScience 29: 1151-1155.

Daily G.C., Ehrlich, P.R. \& Sánchez-Azofeifa G.A. 2001. Countryside biogeography: use of human-dominated habitats by the avifauna of southern Costa Rica. Ecological Applications 11: 1-13.

de Grazio J.W. 1978. World bird damage problems. In: Proceedings of the $8^{\text {th }}$ Vertebrate Pest Conference. Nebraska: University of Nebraska-Lincoln http://digitalcommons.unl.edu/vpc8/13 (Access on 20 April 2019).

Ditt E.H., Mantovani W., Padua C.V. \& Bassi C. 2009. Entrevistas e aplicaçóes de questionários em trabalhos de conservaçáo, p. 617632. In: Cullen-Jr. L.J., Rudran R. \& Padua C.V. (eds.). Métodos de estudos em biologia da conservação e manejo da vida silvestre. Curitiba: Editora da Universidade Federal do Paraná.

Dolbeer R.A. 1990. Ornithology and integrated pest management: Red-winged Blackbirds Agelaius phoeniceus and corn. Ibis 132: 309-322.

Dolbeer R.A. 1998. Population dynamics: the foundation of wildlife damage management for the $21^{\text {st }}$ century, p. 2-11. In: Baker R.O. \& Crabb A.C. (eds.). Proceedings of the $18^{\text {th }}$ Vertebrate Pest Conference. Davis: University of California. https://pdfs.semanticscholar. org/2ad4/c034f8c88b65064a09486365724c328c2bdd.pdf (Access on 20 April 2019).

Fall M.W. \& Jackson W.B. 2002. The tools and techniques of wildlife damage management-changing needs: an introduction. International Biodeterioration and Biodegradation 49: 87-91.

Feare C.J. 1991. Control of bird pest populations, p. 463-478. In: Perrins C.M., Lebreton J.D. \& Hirons G.J.M. (eds.). Bird population studies. Oxford: Oxford University Press.

Fisher A.M. 1992. Vigilance and variation: the key to victory in the vineyard. Australia and New Zealand Wine Industry Journal 7: $140-143$.

Galetti M. 1993. Diet of the Scalyheaded Parrot (Pionus maximiliani) in a semi deciduous forest in south eastern Brazil. Biotropica 25: 419-425.

Gavilanes M.L., Brandão M., Laca-Buendia J.P. \& Araújo M.G. 1995.
Cobertura vegetal da Serra de São José, MG, municípios de São Joâo del Rei e Tiradentes. Daphne 5: 40-72.

Gill E.L., Cotterill J.V., Cowman D.P., Grey C.B., Gurney J.E., Moore N.P., Nadian A.K. \& Watkins, R.W. 1999. All in the worst possible taste: chemical repellents in vertebrate pest management, p. 283-295. In: Cowan D.P. \& Feare C.J. (eds.). Advances in vertebrate pest management. Fürth: Filander Verlag.

Greenberg R., Bichier P. \& Sterling J. 1997. Bird populations in rustic and planted shade Coffee plantations of eastern Chiapas, Mexico. Biotropica 29: 501-514.

IBAMA [Instituto Brasileiro do Meio Ambiente e dos Recursos Naturais Renováveis]. 2004a. Instruçáo Normativa No. 24 de 31 de março de 2004. Diário Oficial da União No. 63, Seção I, p. 90-91.

IBAMA [Instituto Brasileiro do Meio Ambiente e dos Recursos Naturais Renováveis]. 2004b. Instrução Normativa No. 25 de 31 de março de 2004. Diário Oficial da Uniāo No. 63, Seção I, p. 91.

IBAMA [Instituto Brasileiro do Meio Ambiente e dos Recursos Naturais Renováveis]. 2005. Instruçáo Normativa No. 63 de 30 de março de 2005. Diário Oficial da União No. 61, Seçâo I, p. 268.

IBGE [Instituto Brasileiro de Geografia e Estatística]. 2012. Manual técnico da vegetação Brasileira: sistema fitogeográfico, inventário das formaçōes florestais e campestres, técnicas e manejo de coleçōes botanicas e procedimentos para mapeamentos. Rio de Janeiro: IBGE.

Jacinto J.C., Toti T.P., Guaritá R.L. \& Melo C. 2007. Dano em um cultivo de Sorgo (Sorghum bicolor) causado por aves. Anais do VIII Congresso de Ecologia do Brasil. Caxambu: Sociedade de Ecologia do Brasil. https://www.researchgate.net/profile/Celine_Melo/ publication/265947116_DANO_EM_UM_CULTIVO_DE_ SORGO_SORGHUM_BICOLOR_CAUSADO_POR_AVES/ links/55bf82d608aed621de1397b1.pdf (Access on 20 April 2019).

Koopman M.E. \& Pitt W.C. 2007. Crop diversification leads to diverse bird problems in Hawaiian agriculture. Human-Wildlife Conflicts 1: 235-243.

Linz G.M., Homan H.J., Werner S.J., Hagy H.M. \& Bleier W.J. 2011. Assessment of bird management strategies to protect sunflower. BioScience 61: 960-971.

Long J.L. 1985. Damage to cultivated fruit by parrots in the south of western Australia. Australian Wildlife Research 12: 75-80.

Lopes L.E., Malacco G.B., Alteff E.F., Vasconcelos M.F., Hoffmann D. \& Silveira L.F. 2010. Range extensions and conservation of some threatened or little known Brazilian grassland birds. Bird Conservation International 20: 84-94.

Marchini S. \& Crawshaw-Jr. P.G. 2015. Human-wildlife conflicts in Brazil: a fast-growing issue. Human Dimensions of Wildlife 20: 323-328.

Mateus M.B. 2013. Relação entre fauna silvestre e produtores rurais: estudos de casos em Milho (Zea mays L.) e Goiaba (Psidium guajava L.) na Zona da Mata de Minas Gerais. MSc. Dissertation. Viçosa: Universidade Federal de Viçosa.

McLaughlin A. \& Mineau P. 1995. The impact of agricultural practices on biodiversity. Agriculture, Ecosystems \& Environment 55: 201-212.

Messmer T.A. 2009. Human-wildlife conflicts: emerging challenges and opportunities. Human-Wildlife Conflicts 3: 10-17.

Moreira J.R. \& Piovezan U. 2005. Conceitos de manejo de fauna, manejo de população problema e o exemplo da Capivara. Brasília: Embrapa Recursos Genéticos e Biotecnologia.

Naime U.J., Motta P.E.F., Carvalho-Filho A. \& Baruqui A.M. 2006. Avaliação da aptidão agrícola das terras da Zona Campo das Vertentes - $M G$. Rio de Janeiro: Embrapa Solos.

Nyhus P.J., Tilson R. \& Tilson S. 2000. Crop-raiding elephants and conservation implications at Way Kambas National Park, Sumatra, Indonesia. Oryx 34: 262-274. 
OECD-FAO [Food and Agriculture Organization of the United Nations]. 2015. Brazilian agriculture: prospects and challenges, p. 61-108. In: OECD-FAO Agricultural Outlook. Paris: OECD Publishing.

Oliveira-Filho A.T. \& Fluminhan-Filho M. 1999. Ecologia da vegetação do Parque Florestal Quedas do Rio Bonito. Cerne 5: 51-64.

Ormerod S.J. 2002. Applied issues with predators and predation: editor's introduction. Journal of Applied Ecology 39: 181-188.

Paton D.C., Sinclair R.G. \& Bentz C.M. 2005. Ecology and management of the Common Starling (Sturnus vulgaris) in the McLaren Vale region. In: Final report to grape and wine research and development corporation. https://www.wineaustralia.com/ getmedia/7b5d34b7-b026-475d-af15-8738f0e190c8/finalreport (Access on 26 June 2014).

Pinto L.C.L., Mateus M.B. \& Pires M.R.S. 2012. Conhecimento e usos da fauna terrestre por moradores rurais da Serra do Ouro Branco, Minas Gerais, Brasil. Interciencia 37: 520-527.

Pritts M.P. 2001. Bye-bye birdie: repelling birds from fruit plantings. New York Fruit Quarterly 9: 5-7.

Rao A. 2010. Whose right is it anyway? The farmer-ungulate conflict. Current Conservation 4: 16-21.

Saiki P.T.O., Guido L.F.E. \& Cunha A.M.O. 2009. Etnoecologia, etnotaxonomia e valoraçáo cultural de Psittacidae em distritos rurais do Triângulo Mineiro, Brasil. Revista Brasileira de Ornitologia 17: 41-52.

Santos-Neto J.R. \& Gomes D.M. 2007. Predação de milho por Arara-azul-de-Lear, Anodorhynchus leari (Bonaparte, 1856) (Aves: Psittacidae) em sua área de ocorrência no sertâo da Bahia. Ornithologia 2: 41-46.

Simon G. 2008. A short overview of bird control in sweet and sour cherry orchards: possibilities of protection of bird damage and its effectiveness. International Journal of Horticultural Science 14: 107-111.
Sinclair A.R.E., Fryxell J.M. \& Caughley G. 2006. Wildlife ecology, conservation, and management. Malden: Blackwell Publishing.

Singleton G.R., Leirs H., Hinds L.A. \& Zhang Z. 1999. Ecologicallybased management of rodent pests: re-evaluating our approach to an old problem, p. 17-30. In: Singleton G.R., Hinds L.A., Leirs H. \& Zhang Z. (eds.). Ecologically based management of rodent pests. Canberra: Australian Centre for International Agricultural Research.

Somers C.M. \& Morris R.D. 2002. Birds and wine grapes: foraging activity causes small-scale damage patterns in single vineyards. Journal of Applied Ecology 39: 511-523.

Tracey J., Bomford M., Hart Q., Saunders G. \& Sinclair R. 2007. Managing bird damage to fruit and other horticultural crops. Canberra: Bureau of Rural Sciences.

USDA [United States Department of Agriculture]. 1997. Animal damage control program: final environmental impact statement. Washington: United States Department of Agriculture, Animal and Plant Health Inspection Service.

USDA [United States Department of Agriculture]. 2010. Reducing bird damage through an integrated wildlife damage management program in the State of North Carolina: final environmental assessment. Washington: United States Department of Agriculture, Animal and Plant Health Inspection Service.

Valsecchi J. \& Amaral P.V. 2009. Perfil da caça e dos caçadores na Reserva de Desenvolvimento Sustentável de Amaná. Uakari 5: 33-48.

Verhulst J., Báldi A. \& Kleijn D. 2004. Relationship between land-use intensity and species richness and abundance of birds in Hungary. Agriculture, Ecosystems and Environment 104: 465-473.

Associate Editor: Cristiano S. Azevedo. 